\title{
Design, Analysis and Performance Study of PV-Wind-Diesel Generator Hybrid Power System for a Hilly Region Khagrachari of Bangladesh
}

\author{
M. M. H. Prodhan ${ }^{1}$, A. B. M. H. Talukder ${ }^{2}$, M. F. Huq ${ }^{1 *}$, S. K. Aditya ${ }^{2}$ \\ ${ }^{1}$ Department of Nuclear Engineering, University of Dhaka, Dhaka 1000, Bangladesh \\ ${ }^{2}$ Department of Electrical \& Electronic Engineering, University of Dhaka, Dhaka 1000, \\ Bangladesh
}

Received 26 August 2016, accepted in final revised form 3 November 2016

\begin{abstract}
In this research paper, a hybrid power generation system considering Photovoltaic (PV), Wind Turbine and Diesel generator, has been proposed for a hilly region application. The method of this study was the assortment of the elementary data of wind speed, solar radiation and additional requisite input data. The electric renewable energy software hybrid optimization model of renewable energy (HOMER) has been used for design, analysis and performance study of the system. The model has been designed to deliver an optimum pattern based on hour-by-hour data for energy convenience and loads. A number of various performance studiy like sustainability, sensitivity, cost, feasibility is performed in this research. $24 \mathrm{~h}$ primary AC loads, yearly wind speed and PV radiation were analyzed. Analysis divulges that this proposed hybrid power generation system would be feasible alternatives for stand alone application at rural and detached hilly localities.
\end{abstract}

Keywords: HOMER; Hybrid power generation system; Renewable energy; Payback period; Sensitivity; Feasibility.

(C) 2017 JSR Publications. ISSN: 2070-0237 (Print); 2070-0245 (Online). All rights reserved.

doi: http://dx.doi.org/10.3329/jsr.v9i1.29480 J. Sci. Res. 9 (1), 57-66 (2017)

\section{Introduction}

Bangladesh has been facing complications in providing energy to maintain its vast population and financial development. The existing demand for energy exceeds the available resources. At present, it is the time to reflect alternative energy resources. It is obligatory to interconnect marginal energy sources. Renewable energy sources deal a sustainable alternative to the endowment of power in remote areas [1-6]. Renewable

\footnotetext{
Corresponding author: fazlul.huq@du.ac.bd
} 
energy resources like PV, hydro, wind energy, biomass or tide offer a convincing substitute to appliance compelled generators for electricity production [7-9]. Renewable Energy is fresh, olive, hygienic and infinite energy source [10]. Since the renewable sources are natural and climate reliant, these energy resources have unbalanced random activities [11]. Solar radiation and wind speed have complementary activities [12]. The discrete instability of the wind and PV resources can be overwhelmed using hybrid power generation systems with battery backup. Uses of hybrid solar systems [13,14] differ from small power stores for distant household providing electrical energy to village electrification for inaccessible communities. There is adequate research work on hybrid energy system [7,15-19]. An elementary representation of a hybrid PV-Wind- Diesel Generator system with battery packing is shown in Fig. 1. The system entails of wind turbine, diesel generator, solar panels, batteries, and converters i.e. competent to meet the consumption peak capacity load, charge controllers for wind generator and PV panels to deliver energy to the storage at the suitable voltage. When superfluous wind and solar energy are available, the batteries store energy and discharge it for future requiring loads. The extent of the electricity production via the system depends on the universal PV radiation and the wind speediness in overall [9]. Enhancements in PV generation equipment and wind generator have carried chances for consuming wind and PV sources for electric power production [20]. It has been informed that in weak grids, the PV, wind or diesel generator hybrid power system is superior to only PV, wind or diesel generator system as it defeats prompt variation in the output control of the particular source such as the wind generator system [21]. Grid interface of the hybrid power system with battery bank storage recovers system consistency [22,23]. Conversely, these hybrid systems must discourse the concrete aspects of what appears to be realistic from commercial and financial viewpoints. The incompetence to surety reliable, continual output at a cost that can be analogous to conventional electric power generation has been the drawback of PV or wind or diesel generator systems. Consequently, a figure of offgrid hybrid structures, which have received more care, were set up and verified in the older spans [24]. Various writings mentions have debated how to govern the optimal arrangement of a hybrid power generation system. The consequences reveal that, renewable energy based off-grid hybrid generation systems can compete with power from the grid in faraway localities [25,26]. The aim of this research is to investigate payback period, the cost profit and sustainability of a solar-wind-diesel generator hybrid power system for a hilly region Khagrachari of Bangladesh when compared to cost per kilowatt of efficacy power stream. In this research paper, we analysed the consistency of the complete hybrid power generation system, usage of renewable energy resources for energy production, relate cost of electricity and finally sensitivity study exhausting simulating software HOMER. Analysis concludes that the hybrid power generation system with PV-wind-diesel generator provides superior performance in terms of cost and sensitivity. 


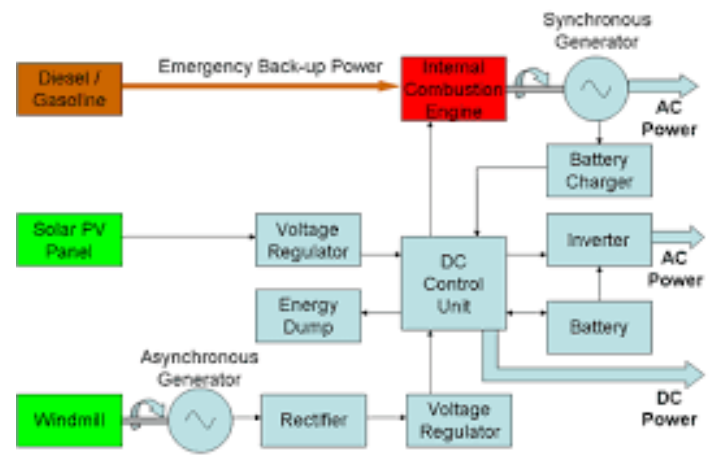

Fig. 1. The proposed hybrid system.

\section{Proposed Hybrid Power System}

\subsection{Selected area}

Khagrachari, geographically situated in Chittagong Division, Bangladesh and its geographical coordinate is $23.0417^{\circ} \mathrm{N} 91.9944^{\circ} \mathrm{E}$, is a suitable region for planning hybrid power generation system since it is not thinkable to launch grid connected system in this hilly zone. For confirming steady and continuous electricity generations, a hybrid power system containing more than one renewable energy resources is presented. In this research paper, natural and cost-effective analyses are used to discuss the sustainability of a hybrid power generation system. An investigation is made on minimal operations of $129 \mathrm{kWh}$ per day hybrid power generation system as a standalone power generation system involving PV, wind turbine and diesel generator.

\subsection{System apparatuses}

A standalone PV, Wind, Diesel generator hybrid power system has been proposed consisting of generic $3 \mathrm{~kW}$ wind energy generator, $5 \mathrm{~kW}$ photovoltaic panels, $5 \mathrm{~kW}$ diesel generator. The system also contains battery, converter and constraints.

\subsection{Primary electric load}

A community of 1500 people, 120 households, one market, two schools and one mosque has been considered for estimation of primary electric load. Two energy efficient lamps (CFL, $15 \mathrm{~W}$ each), two fans (100W each), one color TV (70 W each) for each solvent family are considered. For poor family one energy efficient lamp (CFL, $15 \mathrm{~W}$ each), one fan (100 W each) are considered. Three lights and three fans for each school and one light and one fan for mosque are also considered here. 
Maximum uses of fluorescence light, color TV, Fan are $8 \mathrm{~h}$ per day, $4 \mathrm{~h}$ per day, $5 \mathrm{~h}$ per day. Total electric load profiles are shown in Table 1.

Table 1. Total electric load profile.

\begin{tabular}{|c|c|c|c|c|c|c|c|c|}
\hline \multirow[t]{2}{*}{$\begin{array}{l}\text { Family } \\
\text { Criteria }\end{array}$} & \multirow{2}{*}{$\begin{array}{l}\text { No. } \\
\text { of } \\
\text { Fami } \\
\text { ly }\end{array}$} & \multicolumn{3}{|c|}{$\begin{array}{l}\text { Quantity/per } \\
\text { Family }\end{array}$} & \multirow{2}{*}{$\begin{array}{l}\text { Fluorescence } \\
\text { Light } \\
\text { (kWH/day) }\end{array}$} & \multirow[t]{2}{*}{$\begin{array}{l}\text { Fan } \\
\text { (kWH/day) }\end{array}$} & \multirow{2}{*}{$\begin{array}{l}\text { Color } \\
\text { TV } \\
\text { (kWH } \\
\text { /day) }\end{array}$} & \multirow[t]{2}{*}{$\begin{array}{l}\text { Total } \\
\text { (kWH/day) }\end{array}$} \\
\hline & & Light & Fan & $\mathrm{TV}$ & & & & \\
\hline Solvent & 30 & 2 & 2 & 1 & 7.200 & 30.000 & 15 & 128.84 \\
\hline Poor & 90 & 1 & 1 & 0 & 10.80 & 45.000 & 0 & $\approx 129 \mathrm{kWH} /$ \\
\hline School & 2 & 3 & 3 & 0 & 0.360 & 7.200 & 0 & day \\
\hline Mosque & 1 & 1 & 1 & 0 & 0.030 & 1.000 & 0 & \\
\hline Market & 1 & 4 & 2 & 2 & 0.500 & 2.750 & 9 & \\
\hline Total & & & & & 18.89 & 85.950 & 24 & \\
\hline
\end{tabular}

\subsection{System architecture}

The ratings of the equipments were considered optimistically in the primary step. As a next step, the equipments were considered on optimal basis for providing the financial feasibility of the proposed system. One $5 \mathrm{~kW}$ PV array, two generic $10 \mathrm{~kW}$ wind turbines, one $5 \mathrm{~kW}$ diesel generator, thirty two Surrette $4 \mathrm{KS} 25 \mathrm{P}$ batteries, one $7 \mathrm{~kW}$ converter are considered in this system architecture.

Designing a hybrid power system, information, such as the load profile, for a specific distant location is to be provided that should be met by the proposed hybrid system. Also, the initial cost for each component (diesel, renewable energy generators, battery, converter), cost of diesel fuel, annual interest rate, project lifetime, etc. are to be included.

After selecting this distant locality khagrachari a hilly region of Bangladesh we have collected solar radiation and wind speed data of that locality. Then, we fulfilled the simulation to acquire the preeminent hybrid power system pattern utilizing HOMER software from NREL.

HOMER simulations are performed by analyzing energy balance calculations and showed all the possible configurations arranged by net present cost which can be useful for comparison of system design. HOMER's optimization and sensitivity analysis made this task possible.

\section{Homer Simulation}

An average demand of a general load center with approximately $129 \mathrm{kWh} /$ day is considered. In this analysis, the load is modeled with a few peak demand of almost 18 $\mathrm{kW}$ and a load factor of 0.295 , i.e., the average power divided by the peak power over a span of $24 \mathrm{~h}$ which is shown in Fig. 3. 


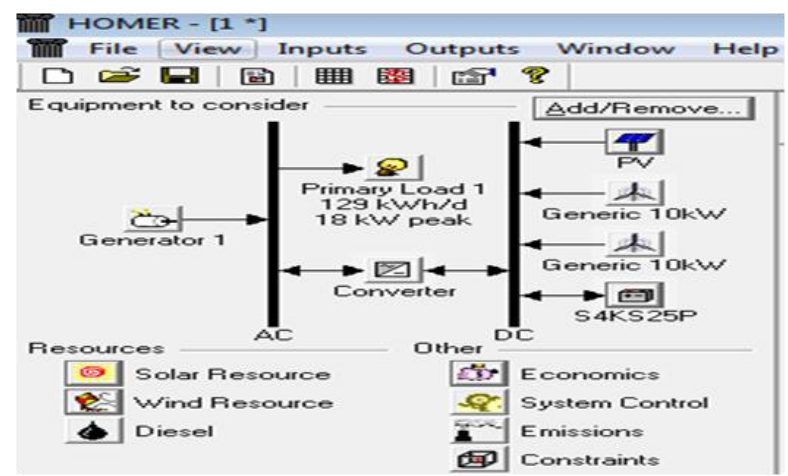

Fig. 2. Proposed hybrid power generation system in homer software.

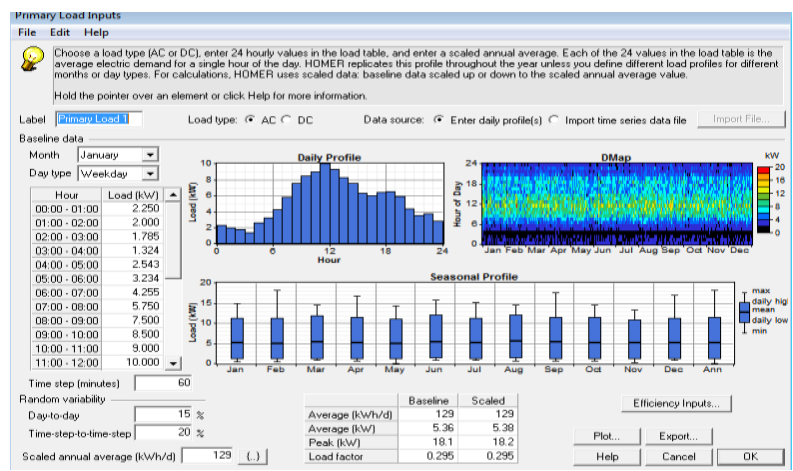

Fig. 3. Load profile of proposed hybrid system.

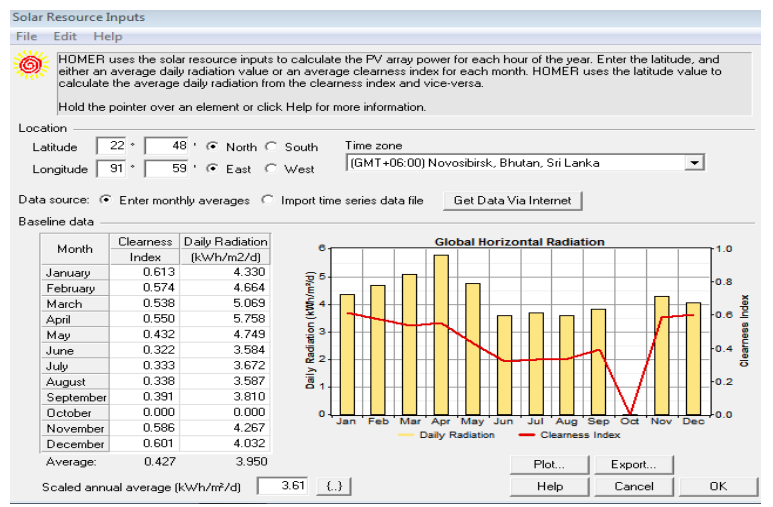

Fig. 4. Solar resources profile of khagrachari, Bangladesh. 


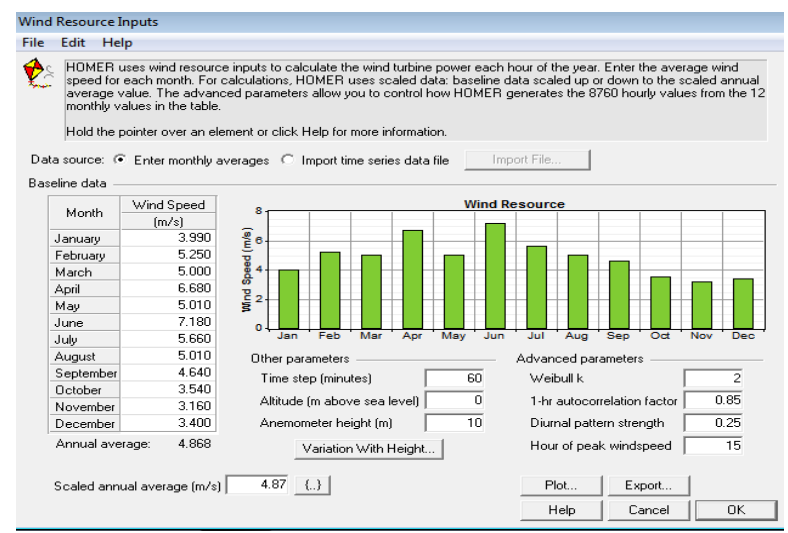

Fig. 5. Wind speed profile of khagrachari, Bangladesh.

Figs. 4 and 5 show the solar radiation profile and wind speed profile of our desired location Rangamati of Bangladesh. Fig. 6 shows the efficiency curve of the proposed system.



Fig. 6. Efficiency curve of the proposed system.

Specification of PV panels, wind turbines, diesel generator, battery, converter, constraint and at sensity case are given in Tables 2-5.

Table 2. Specification of PV panels and wind turbine.

\begin{tabular}{lll}
\hline Component & Size & Life-time \\
\hline PV Panels & $5.00 \mathrm{~kW}$ & 20 years \\
Generic Wind Turbine & $10 \mathrm{~kW} \mathrm{DC}$ & 20 years \\
\hline
\end{tabular}


Table 3. Specification of diesel generator and battery.

\begin{tabular}{llll}
\hline Diesel Generator Profile & Battery Profile & \\
\hline Considered size & $5 \mathrm{~kW}$ & Battery & Surrette 4KS25P \\
Lifetime & $15000 \mathrm{~h}$ & Quantities to consider & $32,34,36,40$ \\
Min. load ratio & $30 \%$ & Voltage & $4 \mathrm{~V}$ \\
Fuel used & Diesel & Nominal capacity & $1,900 \mathrm{Ah}$ \\
Fuel curve intercept & $0.08 \mathrm{~L} / \mathrm{h} / \mathrm{kW}$ & Lifetime throughput & $10,569 \mathrm{kWh}$ \\
& & Min battery life & $4 \mathrm{yr}$ \\
\hline
\end{tabular}

Table 4. Specification of converter and constraints

\begin{tabular}{|c|c|c|c|}
\hline Converter & & Constraints & \\
\hline Sizes to consider & $7 \mathrm{KW}$ & Maximum annual capacity shortage & $0 \%$ \\
\hline Lifetime & $20 \mathrm{yr}$ & Minimum renewable fraction & $0 \%$ \\
\hline Inverter efficiency & $90 \%$ & Operating reserve as percentage of hourly load & $10 \%$ \\
\hline $\begin{array}{l}\text { Rectifier } \\
\text { capacity }\end{array}$ & $100 \%$ & $\begin{array}{l}\text { Operating reserve as percentage of solar power } \\
\text { output }\end{array}$ & $25 \%$ \\
\hline Rectifier efficiency & $85 \%$ & $\begin{array}{l}\text { Operating reserve as percentage of wind power } \\
\text { output }\end{array}$ & $50 \%$ \\
\hline
\end{tabular}

Table 5. Specification at sensitivity case.

\begin{tabular}{ll}
\hline Wind Data Scaled Average & $4.87 \mathrm{~m} / \mathrm{s}$ \\
\hline Diesel Price & $0.8 \$ / \mathrm{L}$ \\
Surrette 4KS25P Capital Cost Multiplier & 1 \\
\hline
\end{tabular}

\section{Results and Discussion}

Figs. 7 and 8 show the optimization results and sensitivity results of HOMER simulation respectively. Using HOMER software the system performance study has been evaluated. The optimized result is analyzed for a solar radiation of 3.61 $\mathrm{kWh} / \mathrm{m}^{2} /$ day, wind speed of $4.87 \mathrm{~m} / \mathrm{s}$, and diesel price of 40 BDT. The results obtained from the current research clearly reveals that, the hybrid power system consisting of one $5 \mathrm{~kW}$ diesel generator, two generic $10 \mathrm{~kW}$ wind turbine, one $5 \mathrm{~kW}$ PV array, 32 batteries and 7 bi-directional converter to link $\mathrm{AC}$ and $\mathrm{DC}$ bus, requires minimal production cost.



Fig. 7. Optimization results of HOMER simulation. 


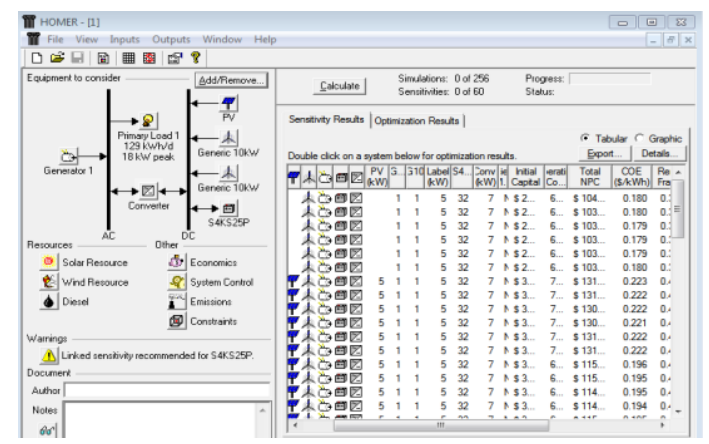

Fig. 8. Sensitivity results of HOMER simulation.

The annual electric energy production, annual electric energy consumption, the production power by individual renewable source are shown in Figs. 9 and 10. Initial cost of such a hybrid power system consisting of one $5 \mathrm{~kW}$ diesel generator, two generic $10 \mathrm{~kW}$ wind turbine, one 5 kW PV array, 32 batteries and 7 bi-directional converter to link AC and DC bus would be $8238000 \mathrm{BDT}$ and it will produce electricity $60887 \mathrm{kWh} / \mathrm{yr}$ at a cost of $13.92 \mathrm{BDT} / \mathrm{kWh}$ (1 USD $=80 \mathrm{BDT})$. So, the total amount of annual income is 847547 BDT $(60887 * 13.92)$ and payback period is approx. 9.7 years. Such a system would result in a renewable energy fraction of 0.483 .

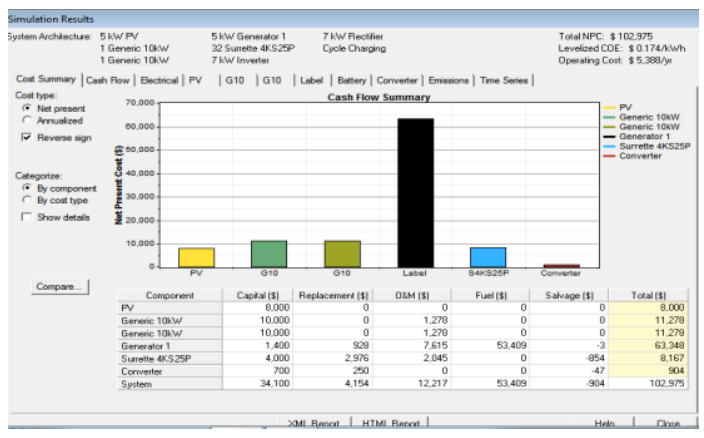

Fig. 9. Cash flow summary result of HOMER simulation.



Fig. 10. Monthly average electric production. 
The levelized cost of energy (COE) is signified in Fig. 11. From optimal system type it is seen that the green part is much wider than blue part for primary load of 129 $\mathrm{kWh} /$ day with diesel price $\$ 0.8 / \mathrm{L}$. The green part reveals the contribution of $\mathrm{PV}$, Wind, generator and battery on sensitivity for the hybrid system while the blue part reveals contribution of wind, generator and battery. Therefore, we can conclude that the designed hybrid system is more reliable in terms of COE.



Fig. 11. Optimal systems in terms of Diesel price and wind speed.

\section{Conclusion}

In our research work the HOMER simulation outcome is encouraging. The designed hybrid system will produce electricity $60887 \mathrm{kWh} / \mathrm{yr}$ at a cost of $13.92 \mathrm{BDT} / \mathrm{kWh}$. The excess electricity generated will be $8.309 \mathrm{kWh} / \mathrm{yr}$. It is also realized that the unmet electric load is almost zero and the payback period is approx. 9.7 years. However, since our proposed system constituents were done optimistically for the desired location khagrachari of Bangladesh, supplementary detailed economic analysis is requisite for practical application.

\section{Acknowledgments}

The authors are thankful to Institute of Energy, University of Dhaka, Bangladesh, for providing the required primary data.

\section{References}

1. A. K. Akella, M. P. Sharma, and R. P. Saini, Renewable Sust. En. Rev. 11, 894 (2007). http://dx.doi.org/10.1016/j.rser.2005.06.006

2. S. Manoj and P. P. Srinivasaiah, Int. J. Emerging Technol. Adv. Eng. 2, 740 (2012).

3. A. B. Kanase-Patil, R. P. Saini, and M. P. Sharma, Renewable En. 35, 1342 (2010).

4. Rajoriya, E. Fernandez, Int. J. Sust. Eng. 3, 219 (2010). http://dx.doi.org/10.1080/19397038.2010.484870

5. A. Gupta, R. P. Saini, and M. P. Sharma, Renewable En. 35, 520 (2010). 
6. A. A. Setiawan, Y. Zhao, and C. V. Nayar, Renewable En. 34, 374 (2009).

7. S. K. Nandi and H. R Ghosh, Energy 35, 3040 (2010). http://dx.doi.org/10.1016/j.energy.2010.03.044

8. N. C. Van, Renewable En. 9, 1161 (1996).

9. J. G. Fantidis, D. V. Bandekas, N. Vordos, J. Eng. Technol. Rev. 8, 6 (2015). https://www.researchgate.net/publication/298083076

10. J. A. Duffe, W. A. Beckman, Solar Engineering of Thermal Processes (John Willey and Sons, New York, 1980).

11. M. A. Elhadidy and S. M. Shaahid, Renewable En. 29, 517 (2004).

12. F. Valencaga, P. F. Puleston, and P. E. Battaiotto, IEEE Trans. En. Conv. 18, 501 (2003).

13. M. Lira-Cantu and F. C. Krebs, Sol. En. Mater. Sol. Cells 90, 2076 (2006). http://dx.doi.org/10.1016/j.solmat.2006.02.007

14. L. Tashmim, T. Debnath, C. H. Rüscher, and A. Hussain, J. Sci. Res. 7, 55 (2015). http://dx.doi.org/10.3329/jsr.v7i1-2.18798

15. S. S. Dihrab and K. Sopian, Renewable En. 35, 1303 (2010).

16. P. Balamurugana, S. Ashok, and T. L. Jose, En. Sources A, 33, 823 (2011). http://dx.doi.org/10.1080/15567030903117646

17. A. H. Al-Badi, M. AL-Toobi, S. AL-Harthy, Z. Al-Hosni, and A. AL-Harthy, Int. J. Sust. En. 31, 411 (2011). http://dx.doi.org/10.1080/14786451.2011.590898

18. A. H. Al-Badi and H. Bourdoucen, Int. J. Sust. En. 31, 85 (2011). http://dx.doi.org/10.1080/1478646X.2011.554608

19. D. K. Lal, B. B. Dash, and A. K. Akella, Int. J. Electr. Eng. Inf. 3, 307 (2011).

20. W. D. Kellogg, M. H. Nehrir, G. Venkataramanan, and V. Greez, IEEE Trans. En. Conv. 13, 70 (1998). http://dx.doi.org/10.1109/60.658206

21. K. Kurozumi, T. Tanaka, Y. Kawagoe, T. Yamanaka, H. Ikebe, K. Shindou, and T. Miyazato - INTELEC Int. Tel. Energy Conf. (1989) pp. 785-789.

22. R. Chedid and S. Rahman, IEEE Trans. En. Conv. 12, 79 (1997). http://dx.doi.org/ 10.1109/60.577284

23. F. Giraud and Z. M. Salameh, IEEE Trans. En. Conv. 16, 1 (2001). http://dx.doi.org/10.1109/60.911395

24. D. Palit and A. Chaurey, OASYS South Asia Research Project Working Paper Series, Working Paper 01, TERI, New Delhi, 1-61 (2011) http://www.academia.edu/4172298/WP1-_South_Asia_off-grid_experience.

25. S. K. Nandia and H. R. Ghoshb, Energy 35, 3040 (2010). http://dx.doi.org/10.1016/j.energy.2010.03.044

26. S. Rehman, I. M. El-Amin, F. Ahmad, S. M. Shaahid, A. M. Al-Shehri, J. M. Bakhashwain, and A. Shash, Renewable and Sust. En. Rev. 11, 635 (2007). 